ACOST never browbeaten

SIR - Your leading article (Nature 363, 381 ; 1993) on the White Paper on British research policy casts doubt on the independence of the Advisory Council on Science and Technology (ACOST) and its successor, the Council for Science and Technology.

During my three-year term of office as chairman of ACOST, I can say categorically that the council has never been "browbeaten by determined ministers and their chief scientific advisers". ACOST has addressed the issues it wished to address and has said what it wanted to say. Certainly, in selecting issues to study, ACOST has taken note of government as well as public concerns, and in suggesting mechanisms for implementing recommendations, ACOST has taken note of government policies. To do otherwise would be foolish and would not be more "independent".

I welcome the establishment of the Council for Science and Technology as a positive development of the role that ACOST has undertaken. The fact that it is to be chaired by the Chancellor of the Duchy of Lancaster, on behalf of the Prime Minister, will place advice on science and technology policy at the heart of the political process in government, which is where it belongs.

Within the Council for Science and Technology, I have no doubt that the independent industrial and academic members of the new council will be more than capable of presenting rigorous independent advice to ministers. Additionally, paragraph 2.41 of the White Paper makes clear the willingness of government to receive high quality independent advice from other sources outside government, not least the quaintly named but, hopefully, very effective National Academies Policy Advisory Group.

Robin Nicholson

Cabinet Office,

Advisory Council on

Science and Technology,

Albany House,

84-86 Petty France,

London SW1H 9ST, UK

\section{Children of choice}

SIR - According to James Watson": "The world must shed the idea that this is evil [abortion of fetuses diagnosed with genetic defects], as it is a true act of moral cowardice to allow children to be born with known genetic defects." The idea is an old one. In ancient Sparta, Olympic athletes were pressed into service to provide the fruit of their loins for the better- ment of Sparta. Weak or malformed infants were exposed ${ }^{2}$. That was no evil because it was done for the benefit of society.

Hermann Muller ${ }^{3}$, who won the Nobel prize for Physiology or Medicine in 1948, considered the benefits of this idea to society in detail. One of his objectives was to free women from the menial servitude of child-bearing and child-rearing by separating sexual intercourse from reproduction. Laboratory methods for culturing and transplanting human ova would "greatly extend the reproductive potencies of females possessing characters particularly excellent, without thereby necessarily interfering with their personal lives." Muller was the first to develop the technique of preserving sperm, human and cattle, in liquid nitrogen.

To be sure, Muller was aware that popular pressure might result in "a maximum number of Billy Sundays (a fundamentalist preacher), Valentinos (an actor), Jack Dempseys (heavyweight boxing champion), Babe Ruths (baseball) and even Al Capones (a gangster)". The contemporary roster of popular heroes is no less disconcerting.

Muller added that the selection of genetic material would be voluntary and that. . . "Compulsion need enter, if at all, only in a negative role, to prevent exploitation of the enhanced possibilities."

Muller's extreme naïveté jumps out at one. The meek may be blessed and inherit the Earth, but they won't keep it long. It is exactly those individuals who are "unduly egotistic, aggressive or paranoid" who will attain the power to choose the genetic heritage of "children of choice".

Hubert P. Yockey

1507 Balmoral Drive,

Bel Air, Maryland 21014, USA

1. Short, N. Nature 362, 783-784 (1993).

2. Haeckel, Ernst The Wonders of Life (Harper, New York \& London, (1905).

3. Muller, Herman J . Out of the Night (Nanguard Press, New York, 1935).

4. Huxley, Aldous, Brave New World \& Brave New World Revisited (Harper \& Row, New York \& London, 1932, 1946, 1958, 1965)

\section{SI units defined}

SIR - The letter "SI units explained" itself demonstrates confusion about the meaning of SI units. Regrettably, the debate continues with little or no reference to the primary recommendations from authoritative intergovernmental organizations $^{2-4}$.

SI units are defined as including base units $(\mathrm{kg}, \mathrm{m}, \mathrm{s}, \ldots, \mathrm{mol})$ and derived units (for example, $\mathrm{kg} \mathrm{s}^{-1}$, $\mathrm{mol} \mathrm{kg}^{-1}$, mol $\mathrm{m}^{-3}$ ). The International System of Units is the coherent system encompassing these units. The authorities also recognize decimal multiples of SI units and give rules on how they should be expressed (for example, $\mathrm{mg} \mathrm{s}^{-1}, \mu \mathrm{mol} \mathrm{kg}{ }^{-1}, \mathrm{nmol} \mathrm{m}^{-3}$ ); these units are not actually classed as SI units, so that their use can be viewed either as a "retreat from SI units" or as a supplementary set of units. There are also "non-SI units which may be used with the SI units and their multiples" 4 or "units outside the International System" recognized for "use with the International System" such as day (d), litre (L), tonne (t). Such units are legally recognized units in the European Communities and in the United States. Choice between them is a matter partly of following the rules in the international agreements but also of taking into account logic, common sense and convenience. For instance, it is more convenient to use an expression with one prefix than two: $\mathrm{g} \mathrm{m}^{-3}$ or $\mathrm{mg} \mathrm{L}^{-1}$ rather than $\mathrm{mg} \mathrm{dL}^{-1}$.

The choice between "mg/dL" and "mmol/L" for cholesterol measurements, however, is a matter of choosing mass concentration and substance concentration of cholesterol; it is not a question of validity of units. That choice ought to be governed by the relative informativeness of the two kinds-of-quantity. In the words adopted by the 30th World Health Assembly (Resolution 30.39 of May 1977): "For a proper understanding of chemical reactions ... the use of the mole is essential. The use of mass units ... serves no purpose other than the purely arbitrary one of deciding whether or not a given value is greater or less than a certain reference value. The expression of concentrations . . . in body fluids in molecular terms also serves this purpose, but in addition gives valuable insight into the balance of the constituents. Such insight cannot be obtained from mass units." This comment was part of a resolution entitled "Use of SI units in medicine"; it can be viewed as a restriction, but it is better to see it positively as a sensible preference.

We urge authors and editors to make the effort to acquire a sound grasp of the definitions and utility of SI units. Although there may be a certain charm ${ }^{5}$ in a multiplicity of measurements, the advantages of consistency seem overwhelming.

J. C. Rigg

Pudoc, PO Box 4,

6700 AA, Wageningen,

Netherlands

S. S. Brown

West Midlands Regional Laboratory

for Toxicology,

Birmingham $B 187 Q H$, UK

1. van Assendelft, O. W. Nature 362, 388 (1993)

2. Le Système international d'Unités (SI) The International System of Units (SI) 6 th edn (Bureau International des Poids et Mesures, Sevres, 1991). [ISBN 92-822-2112-1]

3. Quantities and Units. Pt 0 . General principles ISO 31.0 International Organization for Standardization 1992 [Obtainable from national standardization institutions.]

4. SIUnits and Recommendations for the Use of their Multiples and of Certain Other Units ISO/DIS 1000 (International Organization for Standardization, 1990) [Obtainable from national standardization institutions.] 5. Asten, E. L. Nature 345, 506 (1990). 